\title{
RETROSPECTIVE ANALYSIS OF REOPERATION RATE AFTER STANDARD LUMBAR DISCECTOMY AND MICRODISCECTOMY - SINGLE CENTER EXPERIENCE \\ Vojin Kovacevic $^{1,2}$ and Nemanja Jovanovic ${ }^{2}$ \\ ${ }^{1}$ University of Kragujevac, Faculty of Medical Sciences, Department of Surgery, Kragujevac, Serbia \\ ${ }^{2}$ Center for neurosurgery, Clinical Center Kragujevac, Kragujevac, Serbia \\ *Authors Vojin Kovačević and Nemanja Jovanović contributed equally to this paper
}

\section{RETROSPEKTIVNA ANALIZA UČESTALOSTI REOPERACIJE LUMBALNE DISKUS HERNIJE NAKON STANDARDNE I MIKRODISKEKTOMIJE - ISKUSTVO JEDNOG CENTRA}

\author{
Vojin Kovačević ${ }^{1,2}$ i Nemanja Jovanović ${ }^{2}$ \\ ${ }^{1}$ Univerzitet u Kragujevcu, Fakultet medicinskih nauka, Katedra za Hirurgiju, Kragujevac, Srbija \\ ${ }^{2}$ Centar za neurohirurgiju, Klinički Centar Kragujevac, Kragujevac, Srbija \\ *Autori Vojin Kovačević i Nemanja Jovanović su podjednako učestvovali u istraživanju
}

Received/Primljen: 24.04.2019.

Accepted/Prihvaćen: 01.05.2019.

\begin{abstract}
Discectomy is a surgical procedure in the treatment of lumbar disc herniation $(\mathrm{LDH})$ if sciatica or neurological deficits occur and still persist after a course of conservative therapy. Standard discectomy (SD) and microdiscectomy (MD) are still equal in curent clinical practice. Many retrospective and prospective studies have shown that there is no clinically significant difference in the functional outcome after two treatment modalities.

The aim of our study was to determine whether there are differences in the incidence of reoperation after performing SD and MD.

The research included 545 patients with average period of postoperative follow-up of approximately 5.75 years. Standard discectomy was performed in 393 patients (72.11\%), and microdiscectomy in 152 (27.8\%) patients. The total number of reoperated patients was $37 / 545$, or $6.78 \%$. In the SD group, the number of reoperated patients was 33/393 (8.39\%) and in the MD group $4 / 152$ or $2.63 \%$. Statistically significant difference $(p<0.05)$ was recorded in favor of the MD group.

Although it has been proven that both SD and MD give good endpoints of treatment and similar functional recovery, the advantage is given to microdiscectomy due to statistically significantly lower rates of recurrent herniation. This result is attributed to better visualization of neural structures and pathological substrates, as well as their mutual relationship.
\end{abstract}

Keywords: hernia lumbar discus, microdiscectomy, standard discectomy, reoperation.

\section{SAŽETAK}

Lumbalna diskektomija je hirurška metoda u lečenju pacijenata obolelih usled lumbalne diskus hernije ( $L D H)$ kada neurološki deficit i radikularni bol perzistiraju i nakon konzervativne terapije. Standardna diskektomija (SD) i mikrodiskektomija (MD) su u mnogim centrima još uvek dva ravnopravna modaliteta operativnog lečenja lumbalne diskus hernije. Većina dosadašnjih studija su došle do zaključka da nakon SD i MD nema značajne razlike u krajnjem funkcionalnom ishodu lečenja.

Naš cilj je bio da ustanovimo da li postoji razlika u učestalosti reoperacije u odnosu na inicijalno sproveden modalitet hirurškog lečenja.

Retrospektivnom analizom je obuhvaćeno ukupno 545 pacijenata, sa prosečenim periodom postoperatvinog praćenja od oko 5,75 godina. Standardna diskektomija je primenjena kod 393 pacijenta (72,11\%), a mikrodiskektomija kod 152 (27,8\%) pacijenta. Ukupan broj reoperisanih pacijenata je bio 37 (6,78\%). U SD grupi broj reoperisanih pacijenata je bio 33 (8,39\%), a u MD grupi 4 (2,63\%). Zabeležena razlika se pokazala kao statistički značajna $(p<0,05)$ u korist MD grupe.

Iako je dokazano da SD i MD daju podjednako dobre krajnje rezultate lečenja, prednost dajemo mikrodiskektomiji zbog uočene statistički značajno niže stope rekurentne diskus hernije. Ovaj rezultat pripisujemo boljoj vizuelizaciji neuralnih struktura i patološkog supstrata, kao i njihovog međusobnog odnosa.

Ključne reči: lumbalna diskus hernija, mikrodiskektomija, standardna diskektomija, reoperacija. 


\section{INTRODUCTION}

Intervertebral (iv) disc degeneration is usually the first step in the cascade of pathophysiological processes that lead to various forms of degenerative lumbar spine diseases (1). Further progression of disc degeneration leads to a lumbar disc herniation (LDH), a disease that is the most common cause of low back pain and sciatica (2). Second most common cause for seeing a doctor (after respiratory diseases) is low back pain, according to sickness absence related studies (3). As a result, LDH is an enormous socio-economic problem in both developed and developing countries because it reduces population productivity.

Many pioneers of neurosurgery at the beginning of $20^{\text {th }}$ century had an impact on creating modern way of understanding the influence of LDH in the occurrence of sciatica and neurological deficit (4-7). However, for definitive identification of degenerated disc as the cause of sciatica, as well as for viewpoint that surgical treatment can help the patient, we should be grateful to William J. Mixter and Joseph S. Barr. In 1932, in Massachusetts General Hospital, USA, they performed as a multidisciplinary team (neurosurgeon and orthopedic surgeon) the first planned lumbar discectomy using a transdural approach to the intervertebral disc $(8,9)$. In 1938, on the basis of their experience, the same authors concluded that interlaminar extradural surgical approach is more suitable for herniated lumbar disc (10).

Surgical approach presented by Mixter and Barr, nowadays known as SD, is still present today, accompanied by a number of technical improvements implemented over years, and includes partial hemilaminectomy and partial discectomy. A new era in the operative management of LDH began in the late 70 s of the $20^{\text {th }}$ century by introducing MD in clinical practice. MD as an improved surgical technique implying the use of operating microscope for surgical removal of herniated disc material (12). First results have shown that microdiscectomy was just as efficient as standard discectomy, having certain advantages over the latter (13). Compared with the standard open discectomy, microdiscectomy enabled better visualization of neural structures and their relationship to pathological substrate as well as less extensive hemilaminectomy (14). One of the main microdisectomy benefits is that patients nearly twice as fast return to ordinary life activities (15).

In the second half of the 20th century, many intradiscal techniques have been developed for the treatment of patients with $\mathrm{LDH}$, but they have not become widely accepted into clinical practice due to having a limited range of indications and often unsatisfactory clinical results (16-21). Tubular and endoscopic discectomy, which appear to be generally accepted nowadays, have been proven to be a satisfactory alternative to microdiscectomy but also without significant difference in the treatment outcome (22).

In many medical centers, including our institution, it is still not rare for spinal surgeons to decide for standard discectomy. Therefore, these two treatment modalities in our clinical practice are equal and choice usually depends on the surgeon's familiarity with one of the two methods. Several retrospective and prospective randomized studies have been published so far $(23,24)$, analyzing the relative merits of MD and SD, which imposes a general conclusion that there is no clinically relevant difference in the functional outcome. Some studies, however, are favoring microdiscectomy in several parameters of clinical recovery (25). Although there are many studies that report reoperation rate after an initial LDH surgery, there are few studies that compare the same problem regarding these two operative treatment modalities.

\section{THE AIM OF THE PAPER}

The aim of our study was to determine whether there are differences in the incidence of reoperation after performing SD and MD. Our working hypothesis was that microdiscectomy was associated with a lower reoperation rate due to better visualization of the pathological substrate and neural structures, as well as their relationship (Figure 1).

Figure 1. Intraoperative view under magnification of the operating microscope, white arrow - spinal root, black arrow - extruded disc material

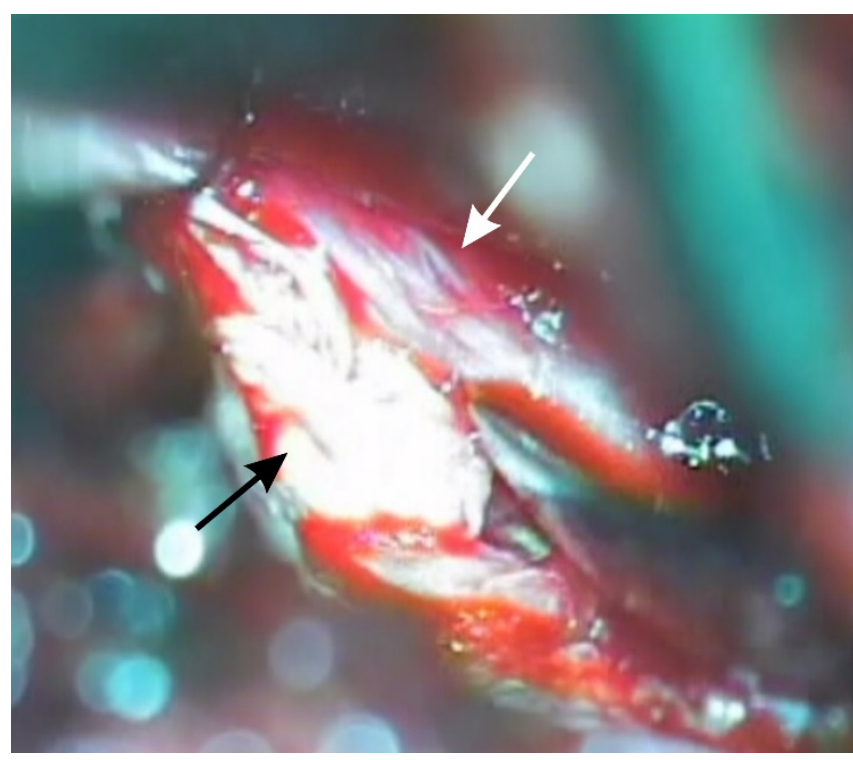

\section{PATIENT AND METHODS}

We conducted a retrospective analysis of recurrent disc herniation rate that required reoperation. Our research involved patients that were surgicaly treated in the period from July 2008 to February 2017 with folow-up period of 68,7 \pm 31 months (approximately 5,75 years). Patients underwent surgery by four experienced neurosurgeons and were classified into two groups, according to performed surgical procedure (MD or SD). 
Operative procedures were performed under general anesthesia and patients were placed in the genupectoral position. The affected interlaminar space was localized by lateral $\mathrm{x}$-ray fluoroscopy just before and with confirmation during surgery. Microdiscectomy was performed after a horizontal skin incision of approximately 4-5 cm in length above the lumbar spinal segments and incision of lumbodorsal fascia and subperiostal preparation to the interlaminar space. Using the operating microscope (Carl Zeiss Co., OPMI Vario/NC33, Oberkochen, Germany), the following aspects of the surgery were performed: partial hemilaminectomy of the superior and inferior lamina and partial flavectomy. After these aspects had been performed, the herniated disc was removed. In addition, all patients were mobilized during the first 24 hours after surgery.

The criteria for inclusion into the study were defined as: single level lumbar disc herniation; monoradicular symptoms

\section{RESULTS}

The study covered a total of 545 patients, of whom 298 (54.7\%) were men and 247 (45.3\%) women. Standard discectomy was performed in 393 patients $(72.11 \%)$, and microdiscectomy in $152(27.8 \%)$ patients. The average age of patients was $46.55 \pm 12.7$ years (M-46.6, F-46.48). Of the total number of patients, only $8.7 \%(47 / 545)$ had a certain degree of preoperative neurological deficits. The most common with predominant sciatica compared to less severe lower back pain; conservative treatment failure or intolerable sciatica, or rapidly progressive neurological deficits (including motor deficits, bladder dysfunction, partial and complete cauda equina syndrome).

Exclusion criteria were defined as: a history of previous lumbar back surgery; signs of spinal instability or other spinal abnormalities and a history of psychiatric or addiction and mental disorders.

Indication for reoperation was recurrent radiculopathy resistant to conservative treatment followed by neuroradiological finding of a compressive lesion.

For statistical analysis the commercial statistical program SPSS (version 22) was used.

level of treated disc herniation was L5/S1 in $48.4 \%$ of cases (264/545), followed by L4/L5 in 41.3\% (225/545). Based on intraoperative findings it was detected that in $36.7 \%$ (200/545) patients had disc protrusion, in 59.3\% (324/545) disc extrusion, and in $2 \%(11 / 545)$ seqestration of iv disc. (Table 1).

Table 1. Parameters by groups and reoperation rate

Total Standard discectomy Microdiscectomy

\begin{tabular}{r|llll} 
Number of patients & 545 & 393 & 152 & $\mathrm{p}>0,05$ \\
Male/female ratio & $\mathrm{M}-298(54,7 \%)$ & $\mathrm{M}-215(54,7 \%)$ & $\mathrm{M}-83(54,6 \%)$ & $\mathrm{p}>0,05$ \\
& $\mathrm{~F}-247(45,3 \%)$ & $\mathrm{F}-178(45,3 \%)$ & $\mathrm{F}-69(45,4 \%)$ & $\mathrm{p}>0,05$ \\
Years old & $46,55 \pm 12,7$ & $46,93 \pm 13$ & $45,06 \pm 11,33$ & $\mathrm{p}>0,05$ \\
Preoperative neuro- & $8,7 \%(47 / 545)$ & $9,4 \%(37 / 393)$ & $6,5 \%(10 / 152)$ & $\mathrm{p}>0,05$ \\
logical disability & & & & $\mathrm{L}$ \\
Spinal level & $\mathrm{L} 5 / \mathrm{S} 1-48,4 \%$ & $\mathrm{~L} 5 / \mathrm{S} 1-49,61 \%$ & $\mathrm{~L} / \mathrm{S} 1-50,6 \%$ & $\mathrm{~L} 4 / \mathrm{L} 5-44,7 \%$ \\
Reoperation rate & L4/L5 - 41,3\% & L4/L5 - 39,9\% & 2,63\% (4/152)
\end{tabular}


The total number of reoperated patients in this retrospective group was $37 / 545$, or $6.78 \%$. In the SD group, the number of reoperated patients was 33/393 (8.39\%) and in the MD group $4 / 152$ or $2.63 \%$. (Figure 2). According to reoperation rate, a statistically significant difference $(p<0.05)$ was recorded in favor of the MD group. Of the total number of reoperated patients, 22 (59.45\%) patients had a verified disc extrusion during the first surgery and in remaining 15 (40.55\%) disc protrusion was diagnosed.

Reoperations were most often performed in the first 6 months after the initial operation in 54.05\% (20/37) of cases and in the period 6-12 months after the operation 8/37 patients were reoperated, or 21.6\% (Figure 3A).

The most common cause of reoperation was recurrent disc herniation in $67.56 \%$ (25/37) of cases. In $18.91 \%$ (7/37) of patients, need for additional decompression due to central or lateral stenosis was indicated as a cause of reoperation. Peridural fibrosis was identified as a pathological substrate in $4(10.81 \%)$ patients and one patient $(2.7 \%)$ was reoperated due to disc herniation at different spinal level (Figure 3B).
Figure 2. Reoperation rate in relation to the examined groups and total number of patients

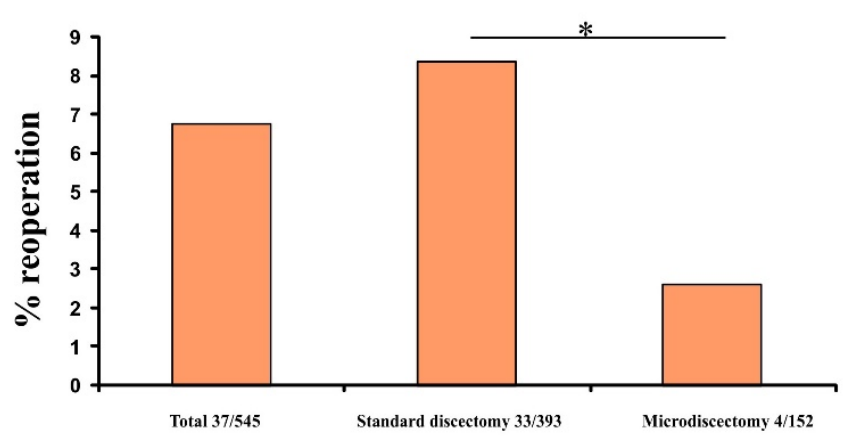

The most commonly surgically retreated spinal level was L5/S1 in 70.2\% (26/37) of cases, followed by L4/L5 in $29.8 \%$ (11/37). Two patients were re-reoperated and both were initially surgically treated with standard discectomy

Figure 3. A - Number of reoperated patients in relation to time elapsed from primary LDH surgery;

B - Frequency of pathology that required reoperation

$\mathbf{A}$

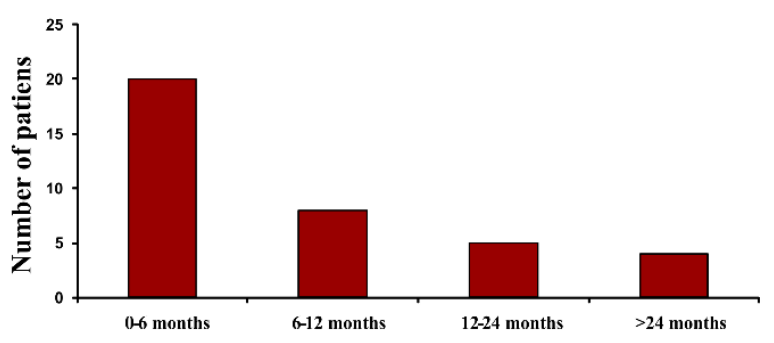

B

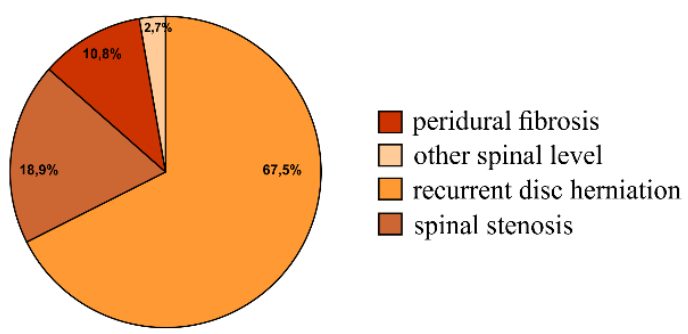

\section{DISCUSSION}

Almost all the papers that analyze the recurrence rate of lumbar disc herniation give an answer to this question including one or more modality of discectomy, but without comparing two surgical procedures. According to them, the recurrence rate, depending on the monitoring period, is 6-24\% [26-29]. A study with a similar follow-up period reported a rate of reoperation of about $10 \%$ [26], which is slightly higher than in our study. This difference in the rate of reoperation does not, however, prove our superior performance in the treatment of lumbar disc herniation, but the reasons may need to be sought in a different set of indications for reoperation. According to a single meta analysis in 2016 [30], the incidence of revision operations, which did not include other reasons than repeated disc-radicular compression, amounted to $1.4-11.4 \%$, while in older patients' series the incidence was lower and amounted to $6 \%$ after a ten-year follow-up period [31]. Our results showed that the total reoperation rate in lumbar disc herniation was 6.78\% (37/545) with an average follow-up period of about 5.75 years. In the SD group, the rate of reoperation was $8.39 \%$ (33/393), while in the MD group it was $2.63 \%$ (4/152). The observed difference was statistically significant in favor of the MD group ( $<0.05)$.

By reviewing the literature, we managed to find only one paper from 2000, which dealt with the comaparison of standard and microdiscectomy with respect to the mentioned problem [32]. According to the aforementioned South Korean group of authors, on a sample of 173 patients, microdiscectomy is associated with a higher rate of reoperation and perioperative infections, which is a conclusion contrary to our results. However, the limitation of this study is that all operations were taken by one surgeon.

The reason for repeated operations in our series, in most cases, was the recurrent disk herniation at the same level in $67.56 \%$ (25/37). Some form of spinal stenosis was the next 
most common cause of reoperation, $18.91 \%$ (7/37), and other reasons were peridural fibrosis $(4 / 37 ; 10.81 \%)$ and discus herniation at the second spinal level $(1 / 37 ; 2.7 \%)$. According to other authors [33], the most frequent reason for the repeated operation of discus hernia was recurrent discus hernia (78\%), followed by epidural fibrosis (12.2\%), and in other cases: adhesive arachnoiditis, lateral spinal stenosis and iatrogenic instability.

Risk factors of the recurrent disc herniation mentioned in the literature arelarge anular defect, the degree of degeneration of the iv disc, male sex, the consumption of nicotine and the lifting of heavy objects [34, 35]. According to a prospective study conducted by Carragee et al. [36] the lowest risk of re-herniation $(1 \%)$ were found in patients with extrusion of the fragment of the disc due to fissure on the fibrous ring. Patients with a major defect on the anulus had a significantly higher risk (27\%), while the highest risk of reherniation was found in a patients with intervertebral disc protrusion (36\%). It should be noted that these are not percentages of reoperation due to the re-herniations of the disk, but only symptomatic re-herniations. In our study of 37 reoperated patients due to a recurrent discus hernia, 21 had iv disc extrusion, and 16 patients had protruded iv disc preoperatively.

In obese patients with a BMI over 30, results are pretty contraversal. According to several authors, obesity does not significantly affect the occurrence of recurrent disc herniation [38, 39], while the results of several other studies claim that the obesity still has an effect [37]. We did not examine the influence of obesity on reoperation rate.

In the study group, which analyzed the rate of recurrent disc herniations in large patient groups, two studies highlighted. A large study that retrospectively analyzed the incidence of reoperation after discectomy in 7520 patients with an average follow-up period of 7 years resulted in an incidence of about $6.2 \%$ [40]. According to the second large retrospective study that included 13654 patients from the United States, the incidence of reoperation was higher after 4 years of follow-up and it amounted to $12.2 \%$, and in almost half of the cases (5.9\%), lumbar fusion surgery was performed [41]. The data on the high incidence of need for lumbar fusion after initial discectomy may indicate an incorrect treatment algorithm for these patients or the result of inadequate operating techniques that have caused the spinal column instability.

In our group of patients, as much as $75 \%$ of the reoperation was performed during the first year after the primary $\mathrm{LDH}$ operation. If we look at the frequency of reoperation within the first year after surgery, it was 5.23\% (28/535). According to the literature data, the rate of early re-herniation, i.e. within one year after surgery is about $1-2 \%$ [31, 42]. It has been shown that the recurrence of the disc herniation is correlated with the degree of degeneration of the disc, as well as with the patient's age at the time of the first operation. More precisely, the recurrence of disk re-herniation is much more common in people in the third and fourth decade of life, as well as in the group with disc protrusion in the first operation [28]. In our study, the average age of reoperated patients did not deviate significantly from the average of the entire study group.

Among reoperated patients the best results of post-operative recovery can be expected in patients with recurrent disc herniation [33]. In general, good treatment result in reoperated patients is recorded in 50-70\% of cases [43-45]. Lateral decompression is advised in order to achieve better results when reintervention is caused by lumbar disc re-herniation, i.e. removing the medial half of the facete joint all the way to the upper facet surface and then the microdiscectomy [46]. Factors that contribute to the poor outcome of post-operative treatment are: reoperation on the same side of the first operation and less than one year after the first operation [43]. Although the revision surgery in which was not found reherniated disc does not have such a good outcome, it significantly reduces the pain syndrome [27]. However, before making a decision on reoperation, the clinical and neuroradiological findings should be carefully analyzed and the operation should be indicated if the preoperative evaluation clearly indicates the existence of surgicaly corrective compression. The incidence of complications during $\mathrm{LDH}$ revision operations according to different authors is $0-34.6 \%$, and the most common complication is the incidental durotomy [30].

\section{CONCLUSION}

Despite evident progress in the treatment of lumbar disc herniation, both by conservative methods and operative techniques, this disease still represents a major problem of the modern world.

As a special problem, criteria for the selection of patients for surgical treatment are imposed as there are no clearly adopted criteria that can be universally applied to each patient. This applies, first of all, to patients who do not have a neurological deficit, and to the group of patients whose pain partially or completely interferes with everyday life activities.

This decision is further aggravated by the relatively high frequency of recurrent complaints, that is, the unfavorable outcome of surgical treatment.

Although it has been proven that both SD and MD give good endpoints of treatment and similar functional recovery, the advantage is given to microdiscectomy due to statistically significantly lower rates of recurrent herniation. This result is attributed to better visualization of neural structures and pathological substrates, as well as their mutual relationship. 


\section{REFERENCE}

1. M. Joković. Degenerativna oboljenja lumbosakralnog dela kičme. In: M Samardzic. Savremena neurohirurgija. 1st ed. Beograd: IP Obelezja plus; 2013; 174.

2. Schwarzer AC, Aprill CN, Derby R, Fortin J, Kine G, Bogduk N. The prevalence and clinical features of internal disc disruption in patients with chronic low back pain. Spine (Phila Pa 1976) 1995; 20:1878-1883.

3. Winn H. In: Youmans \& Winn Neurological Surgery. 7th ed. Elsevier. 2016; 4.

4. Goldthwait JE. The lumbosacral articulation. An explanation of many cases of "lumbago","sciatica" and paraplegia. Boston Medical and Surgical Journal 1911; 164:365-372.

5. Dandy WE. Loose cartilage from intervertebral discs simulating tumour of the spinal cord. The Archives of Surgery 1929; 19:660-672.

6. Middleton GS, John TH. Injury of the spinal cord due to rupture of an intervertebral disc due to muscular effort. The Glasgow Medical Journal 1911; 76:1-6.

7. Mixter W, Barr J. Rupture of the intervertebral disc with involvement of the spinal canal. The New England Journal of Medicine 1934; 211:210-215.

8. Parisien RC, Ball PA. William Jason Mixter (18801958). Ushering in the "dynasty of the disc". Spine (Phila Pa 1976) 1998; 23:2363-2366.

9. Howard S. An. Principles and techniques of spine surgery. Philadelphia. Williams\&Wilkins. 1997.

10. Truumees E. A history of lumbar disc herniation from Hippocrates to the 1990s. Clinical Orthopaedics and Related Research 2015; 473:1885-1895.

11. Peul WC, et al. Surgery versus prolonged conservative treatment for sciatica. The New England Journal of Medicine 2007; 356:2245-2256.

12. Caspar W. A new surgical procedure for lumbar disc herniation causing less tissue damage through a microsurgical approach. Advances and Technical Standards in Neurosurgery 1977; 4:74-80.

13. Williams RW. Microlumbar discectomy: a conservative surgical approach to the virgin herniated lumbar disc. Spine 1978; 3:175-182.

14. M. Samardžić i sar. Osnovi neurohirurgije za sve lekare. Beograd. Zavod za udžbenike i nastavna sredstva; 1998.

15. Wilson DH, Harbaugh R. Microsurgical and Standard Removal of the Protruded Lumbar Disc: A Comparative Study. Neurosurgery 1981; 8:422-427.

16. Greenberg MS. Spine and spinal cord in Handbook of Neurosurgery. 8th Edition. New York Thieme 2016; 1102.

17. Schreiber A, Yoshinori S, Hansjoerg L. Does Percutaneous Nucleotomy With Discoscopy Replace Conventional Discectomy? Eight Years of Experience and Results in Treatment of Herniated Lumbar Disc. Clinical Orthopaedics and Related Research 1989; 238:35-42.
18. Yeung AT, Tsou PM. Posterolateral Endoscopic Excision for Lumbar Disc Herniation: Surgical Technique, Outcome, and Complications in 307 Consecutive Cases. Spine 2009; 27:722-731.

19. Chatterjee S, Foy PM, Findlay GF. Report of a Controlled Clinical Trial Comparing Automated Percutaneous Lumbar Discectomy and Microdiscectomy in the Treatment of Contained Lumbar Disc Herniation. Spine 1995; 20:734-738.

20. Jaikumar S, Kim DH, Kam AC. History of minimally invasive spine surgery. Neuorsurgery (Suppl5) 2002; 51:S1-14.

21. Muto M, Andreula C, Leonardi M. Treatment of herniated lumbar disc by intradiscal and intraforaminal oxygen-ozone (O2-O3) injection. Journal of Neuroradiology 2004; 31:183-189.

22. Gempt J, Jonek M, Ringel F, Preuß A, Wolf P, Ryang Y. Long-term follow-up of standard microdiscectomy versus minimal access surgery for lumbar disc herniations. Acta Neurochirurgica 2013; 155:2333-2338.

23. Burkhardt WB, Grimm M, Schwerdtfeger K, Oertel Joachim MK. 318 Lumbar Disc Surgery: Clinical Outcome of 85 Patients With a Mean Follow-up of 32 Years. Neurosurgery 2016; 63:192.

24. Schmid SL, Wechsler C, Farshad M, Antoniadis A, Ulrich $\mathrm{NH}$, Min K, et al. Surgery for lumbar disc herniation: Analysis of 500 consecutive patients treated in an interdisciplinary spine centre. Journal of Clinical Neuroscience 2016; 27:40-43.

25. Porchet F, Bartanusz V, Kleinstueck FS, Lattig F, Jeszenszky D, Grob D, et al. Microdiscectomy compared with standard discectomy: An old problem revisited with new outcome measures with in the framework of a spine surgical registry. Euro Spine Journal (Suppl 3) 2009; 18:360-366.

26. Kim CH, Chung CH, Park CS, Choi B, Kim MJ, Park BJ. Reoperation Rate After Surgery for Lumbar Herniated Intervertebral Disc Disease: Nationwide Cohort Study. Spine 2013, 38:581-590.

27. Erbayraktar S, Acar F, Tekinsoy B, Acar U, Guner EM. Outcome Analysis of Reoperations after Lumbar Discectomies: a Report of 22 Patients. Kobe Journal of Medical Sciences 2002; 48:33-41.

28. Kim MS, Park KW, Hwang C, Lee YK, Koo KH, Chang BS, Lee CK, Lee DH. Recurrence Rate of Lumbar Disc Herniation After Open Discectomy in Active Young Men. Spine 2009; 34:24-29.

29. Thome C, Barth M, Scharf J, Schmiedek P. Outcome after lumbar sequestrectomy compared with microdiscectomy: a prospective randomized study. Journal of Neurosurgery Spine 2005; 2:271-278.

30. Yoshihara H, Chatterjee D, Paulino CB, Errico TJ. Revision Surgery for "Real” Recurrent Lumbar Disk Herniation: A Systematic Review. Clinical Spine Surgery 2016; 29:111-118. 
31. Davis RA. A long-term outcome analysis of 984 surgically treated herniated lumbar discs. Journal of Neurosurgery 1994; 80:415-421.

32. Kang YH, Lee WS, Yune SH. Comparison of the Results between Standard Discectomy and Microdiscectomy of the Herniated Lumbar Disc. Journal of Korean Society of Spine Surgery 2000; 7:228-233.

33. Serdar O, Sait N, Memet MO, Necmettin PM. Findings and Outcome of Revision Lumbar Disc Surgery. Journal of Spinal Disorders 1999; 12:287-292.

34. Miwa S, Yokogawa A, Kobayashi T, Nishimura T, Igarashi K, Inatani H, et al. Risk Factors of Recurrent Lumbar Disk Herniation: A Single Center Study and Review of the Literature. Journal of Spinal Disorders and Techniques 2015; 28:265-269.

35. Kyoung-Tae K, Dong-Hyun L, Dae-Chul C, JooKyung S, Young-Baeg K. Preoperative Risk Factors for Recurrent Lumbar Disk Herniationin L5-S1. Journal of Spinal Disorders and Techniques 2015; 28:571577.

36. Carragee EJ, Han MY, Suen PW, Kim D. Clinical Outcomes After Lumbar Discectomy for Sciatica: The Effects of Fragment Type and Anular Competence. The Journal of Bone and Joint Surgery 2003; 85:102-108.

37. Meredith DS, Huang RC, Nguyen J, Lyman S. Obesity increases the risk of recurrent herniated nucleus pulposus after lumbar microdiscectomy. Spine 2010; 10:575-580.

38. Rihn JA, Kurd M, Hilibrand AS, Lurie J, Zhao W, Albert $\mathrm{T}$, et al. The influence of obesity on the outcome of treatment of lumbar disc herniation: analysis of the Spine Patient Outcomes Research Trial (SPORT). The Journal of Bone and Joint Surgery 2013; 95:1-8.
39. Quah C, Syme G, Swamy GN, Nanjayan S, Fowler A, Calthorpe D. Obesity and recurrent intervertebral disc prolapse after lumbar microdiscectomy. Annals of The Royal College of Surgeons of England 2014; 96:140-143.

40. Virk SS, Diwan A, Phillips FM, Sandhu H, Khan SN. What is the Rate of Revision Discectomies After Primary Discectomy on a National Scale? Clinical Orthopaedics and Related Research 2017; 475:2752-2762.

41. Heindel P, Tuchman A, Hsieh PC, Pham MH, D'Oro A, Patel NN, et al. Reoperation Rates After Singlelevel Lumbar Discectomy. Spine (Phila Pa 1976) 2017; 42:496-501.

42. Wera GD, Marcus RE, Ghanayem AJ, Bohlman HH. Failure within one year following subtotal lumbar discectomy. The Journal of Bone and Joint Surgery 2008; 90:10-15.

43. Silvers HR, Lewis P, Asch HL, Clabeaux DE. Lumbar Diskectomy for Recurrent Disk Herniation. Journal of Spinal Disorders 1994; 7:408-419.

44. Herron L. Recurrent Lumbar Disc Herniation: Results of Repeat Laminectomy and Discectomy. Journal of Spinal Disorders 1994; 7:161-166.

45. Li-Yang D, Qing Z, Wei-Fang Y, Lei S. Recurrent lumbar disc herniation after discectomy: outcome of repeat discectomy. Surgical Neurology 2005; 64:226231.

46. Albayrak S, Ozturk S, Durdag E, Ayden O. Surgical management of recurrent disc herniations with microdiscectomy and long-term results on life quality: Detailed analysis of 70 cases. Journal of Neurosciences in Rural Practice 2016; 7:87-90. 